\author{
Prof. dr hab. Stanisław SWADŹBA \\ Uniwersytet Ekonomiczny w Katowicach \\ e-mail: stanislaw.swadzba@ue.katowice.pl \\ ORCID: 0000-0002-9006-3595
}

DOI: $10.15290 /$ oes.2021.01.103.05

\title{
MODELE GOSPODARKI RYNKOWEJ A WZROST GOSPODARCZY I JEGO WAHANIA ${ }^{1}$
}

\begin{abstract}
Streszczenie
Cel - Celem niniejszego artykułu jest pokazanie wpływu systemu gospodarczego (modelu gospodarczego) na tempo wzrostu gospodarczego oraz jego wahania.

Metoda badań - Wykorzystano różne metody badawcze: analizę opisową, analizę porównawczą funkcjonujących systemów gospodarczych oraz analizę danych statystycznych dotyczących wzrostu gospodarczego w 12 krajach. Analiza ilościowa została oparta na ostatnich dostępnych danych Eurostatu i Banku Światowego.

Wnioski - Tempo wzrostu gospodarczego oraz jego wahania są zróżnicowane w poszczególnych krajach. Jednak między niektórymi z nich istnieje duże podobieństwo. Najczęściej są to kraje o podobnym systemie gospodarczym. Najbardziej zbliżone do siebie są kraje reprezentujące model śódziemnomorski oraz model społecznej gospodarki rynkowej. O pewnym podobieństwie możemy również mówić w przypadku krajów zaliczanych do modelu neoliberalnego, a jego braku w modelu państwa dobrobytu. Najgorzej ze wzrostem gospodarczym oraz jego stabilnością radzą sobie kraje reprezentujące model śródziemnomorski. Z kolei stabilność wzrostu gospodarczego i dobre radzenie sobie z cyklicznością charakterystyczne jest dla państw realizujących model społecznej gospodarki rynkowej.

Oryginalnośćlwartość - W artykule podjęto zagadnienia, które w są rzadko prezentowane w literaturze. W pewnym stopniu uzupełnia on więc istniejącą lukę badawczą.
\end{abstract}

Słowa kluczowe: analiza porównawcza systemów gospodarczych, wzrost gospodarczy

\section{MODELS OF THE MARKET ECONOMY AND ECONOMIC GROWTH AND ITS FLUCTUATIONS ${ }^{2}$}

\begin{abstract}
Summary
Pupose - The purpose of this article is to show the impact of the economic system (economic model) on the rate of economic growth and its fluctuations.

Research method - Various research methods were used, including: descriptive analysis, comparative analysis of the economic systems and the analysis of statistical data on economic growth in 12 countries. The quantitative analysis was based on the latest available statistical data from the Eurostat and the World Bank database.
\end{abstract}

1 Artykuł wpłyną 20 grudnia 2020 r., zaakceptowano 12 lutego 2021 r.

2 Article received on 20 December 2020, accepted on 18 February 2020. 
Results - The economic growth rate and its fluctuations vary across countries. However, some of them are very similar. Most often these are the countries with a similar economic system. The countries that represent the Mediterranean model and the social market economy model are the most similar. We can also speak of a certain similarity in the case of countries belonging to the neoliberal model, and its lack in the welfare state model. Countries representing the Mediterranean model cope with economic growth and its stability in the worst way. On the other hand, the stability of economic growth and good coping with cyclicality are characteristic of the countries implementing the social market economy model.

Originality / value - This article deals with issues that are rarely discussed in the literature. So, to some extent, it completes the existing research gap.

Key words: comparative analysis of economic systems, economic growth

JEL Classification: P51

\section{Wstęp}

Wzrost gospodarczy jest podstawową kategorią makroekonomiczną będącą przedmiotem badań, odkąd powstała ekonomia jako nauka. Wraz z pojawieniem się interwencjonizmu państwowego wzrost gospodarczy stał się również jednym z głównych celów polityki gospodarczej. Celem tym nie było wyłącznie utrzymanie wysokiego tempa wzrostu gospodarczego, ale $-\mathrm{z}$ czasem w coraz większym stopniu - zmniejszenie jego wahań.

Zaangażowanie się państwa $\mathrm{w}$ powyższe kwestie było $\mathrm{w}$ przeszłości, jak i pozostaje obecnie, zróżnicowane. Wpływa na to m.in. przyjęty model gospodarczy. Jak wiadomo, nie ma bowiem jednego kapitalizmu, jednej gospodarki rynkowej. Rola państwa w gospodarce jest jednym z wyznaczników funkcjonującego w danym kraju systemu gospodarczego.

Celem niniejszego artykułu jest pokazanie wpływu systemu gospodarczego (modelu gospodarczego) na tempo wzrostu gospodarczego oraz jego wahania.

Analizą objęto cztery modele gospodarki rynkowej: neoliberalny, społecznej gospodarki rynkowej, państwa dobrobytu oraz śródziemnomorski. Do każdego modelu przypisano po 3 kraje, które powszechnie uznaje się za najbardziej reprezentatywne. Są to: USA, Wielka Brytania, Irlandia (model neoliberalny), Niemcy, Austria, Holandia (model społecznej gospodarki rynkowej), Szwecja, Dania, Norwegia (model państwa dobrobytu) oraz Włochy, Hiszpania i Grecja (model śródziemnomorski).

Zakres czasowy badań obejmuje ostatnie 15 lat, od 2004 do 2018 roku. W okresie tym zawiera się jeden z większych kryzysów w gospodarce światowej po II wojnie światowej - kryzys I dekady XXI wieku (2008/2009).

W badaniach wykorzystano dane statystyczne Eurostatu oraz Banku Światowego. Wnioski sformułowano w odniesieniu do następujących wskaźników: średnioroczne tempo wzrostu PKB w różnych okresach, różnica między nimi, amplituda wahań, liczba lat $\mathrm{z}$ ujemnym lub niskim tempem wzrostu gospodarczego oraz zmiana poziomu PKB w stosunku do średniej unijnej (UE-28). 


\section{O modelach gospodarki rynkowej (przegląd literatury)}

W literaturze ekonomicznej - zarówno polskiej, jak i zagranicznej - występują różne modele gospodarki rynkowej czy kapitalizmu (jest to szersze pojęcie, które obejmuje nie tylko system gospodarczy, ale także system polityczny i kulturowy). Liczba ich jest dość znaczna. Trzeba jednak podkreślić, że stosuje się różne nazewnictwo dla tych samych modeli, odmienne kryteria ich podziału, a także wyróżnia się je na podstawie większej lub mniejszej liczby wyznaczników (najczęściej są to: system własności, poziom ingerencji państwa w gospodarkę, poziom socjalnego zabezpieczenia obywateli itp.).

W polskiej literaturze zagadnienia te były szeroko omawiane wraz z rozpoczęciem transformacji systemowej - na początku lat 90. XX wieku - w kontekście docelowego modelu polskiej gospodarki. Wyróżniano m.in. takie modele, jak: gospodarka liberalna, neoliberalna, model anglosaski, społeczna gospodarka rynkowa, model skandynawski, socjaldemokratyczna gospodarka rynkowa, model japoński, kapitalizm azjatycki, gospodarka rynkowa ,azjatyckich tygrysów”, model europejski, unijny, śródziemnomorski, a także - rzadziej - takie modele, jak reński, etatystyczny romański czy mieszany model austriacki. Jak widać, często używano odmiennych nazw dla identycznych lub bardzo podobnych modeli. $\mathrm{Na}$ ten temat pisali: W. Wilczyński, A. K. Koźmiński, H. Chołaj, T. Kowalik, S. Kozłowski, L. Balcerowicz, A. Wojtyna i wielu innych ${ }^{3}$. Z czasem przedmiotem zainteresowań stały się odmiany kapitalizmu wyłaniające się w dawnych krajach socjalistycznych, które zakończyły proces transformacji $1^{4}$.

W literaturze zagranicznej Albert [1994] wyróżnia dwa przeciwstawne modele kapitalizmu - model anglosaski (amerykański) i nadreński (niemiecko-japoński). Takie dychotomiczne podejście występuje również u Halla i Soskice’a [2001], którzy - na podstawie sposobu koordynacji działań gospodarczych - wyróżniaja gospodarki rynkowe oparte na koordynacji oraz gospodarki liberalne. Z kolei trzy modele wyróżnia Coates [2000]. Są to: 1. kapitalizm oparty na rynku (market-led capitalism) w praktyce jest to znany model amerykański lub anglosaski, 2. kapitalizm kierowany przez państwo (state-led capitalism) - to tzw. kapitalizm azjatycki (Japonia, Korea Południowa) oraz 3. kapitalizm oparty na negocjacjach lub na konsensusie (negotiated or consensual capitalism) - to europejski kapitalizm opiekuńczy występujący głównie w krajach skandynawskich i Niemczech. Z czterema modelami możemy się spotkać u Huttona [1996]. Należą do nich: kapitalizm brytyjski, amerykański, japoński i „społeczno-rynkowy europejski” (European social market). Pięć modeli wyróżnia Amable [2003], który jako podstawę (kryteria) ich wyróżnienia przyjął: rodzaj i zakres konkurencji na rynku produktów, sposób organizacji rynku pracy oraz wpływ podmiotów tego rynku na wysokość płac, sposób organizacji sektora

\footnotetext{
3 Ze względu na obszerność, a także dużą znajomość powyższych zagadnień nie będzie prezentowana bibliografia na ten temat.

4 Obszerny przegląd badań na ten temat przedstawili: Rapacki, Gardawski, Czerniak, Horbaczewska, Karbowski, Maszczyk, Próchniak [2018].
} 
pośrednictwa finansowego oraz nadzoru właścicielskiego, zakres ochrony socjalnej i państwa opiekuńczego oraz sposób organizacji sektora edukacji. Sa to: 1. model anglosaski (Wielka Brytania, USA, Australia, Nowa Zelandia, Irlandia), 2. model socjaldemokratyczny (Szwecja, Norwegia, Dania), 3. model kontynentalny europejski (Francja, Austria, Holandia, Niemcy), 4. model śródziemnomorski (Grecja, Włochy, Hiszpania i Portugalia), 5. model azjatycki (Japonia i Korea). Ten podział wydaje się najbardziej rozbudowany i sensowny ${ }^{5}$. Warto jeszcze wspomnieć o pięciu modelach Aigingera i Gugera [2005]. Sa to: 1. model anglosaski (liberalny, zamorski), 2. europejski model kontynentalny (korporacyjny lub nadreński), 3. skandynawski, 4. śródziemnomorski oraz 5. model nadrabiania dystansu (catcbing-up mode), do którego zaliczają się gospodarki nowych państw członkowskich UE (transformujących swoje gospodarki).

Nie sa to oczywiście wszystkie klasyfikacje gospodarki rynkowej (kapitalizmu). Ponadto w literaturze przedmiotu - zwłaszcza w: socjologii, naukach o zarządzaniu, politologii, filozofii - pisze się o tzw. kulturach kapitalizmu, by podkreślić jego zróżnicowanie. W wielu publikacjach szeroko omawia się kulturowe zróżnicowanie kapitalizmu bez dokonywania jego klasyfikacji ${ }^{6}$. Nie ma bowiem jednej gospodarki rynkowej, jednego kapitalizmu. Były one, są i z pewnością dalej będą zróżnicowane.

O ile literatura na temat modeli gospodarki rynkowej (kapitalizmu) jest bardzo obszerna, o tyle rzadziej spotykamy się z prezentacjami ich wpływu na wzrost gospodarczy. Raczej pisze się o systemowych czy instytucjonalnych uwarunkowaniach wzrostu gospodarczego. Zwraca się uwagę na systemy instytucjonalne, które są siłą napędową gospodarki, chociaż istnieją również systemy instytucjonalne generujące bariery wzrostu [Balcerowicz, 2008]. Próbuje się wyjaśnić wpływ na wzrost gospodarczy takich determinant, jak: czynniki społeczno-kulturowe, czynniki polityczne (system sprawowania władzy: demokracja czy system autorytarny), system własności i jej ochrona, mechanizm regulacji rynku dóbr oraz czynników wytwórczych, wpływ nierówności na wzrost gospodarczy, istniejący system finansowy itp. [Systemowe uwarunkowania..., 2013]. Wpływ tych uwarunkowań na ogół nie jest jednoznaczny, często $\mathrm{w}$ jednych krajach jest on pozytywny, a w innych negatywny, a także odmiennie działał $\mathrm{w}$ różnych okresach $\mathrm{w}$ tych samych państwach. Wydaje się, że w największym stopniu przedmiotem badań jest wpływ wolności gospodarczej na wzrost gospodarczy. Zajmuja się tym głównie The Heritage Foundation i Fraser Institute. W ostatnim raporcie The Heritage Foundation stwierdzono, że wraz ze wzrostem wolności gospodarczej gospodarka światowa się rozwija, a poziom ubóstwa maleje. Istnieje korelacja $(0,64)$ między poziomem wolności gospodarczej a wielkością $\mathrm{PKB}$ per capita $(\mathrm{PPP})^{7}$. A co najważniejsze, istnieje zależność między średnim tempem wzrostu PKB per capita a tempem zmian wolności gospodarczej.

\footnotetext{
${ }^{5}$ Szerzej na temat powyższych modeli piszą m. in. [Wojtyna, 2005; Maszczyk, 2015].

${ }^{6} \mathrm{O}$ zróżnicowaniu kapitalizmu z punktu widzenia kulturowego pisali: C. Hampden-Turner i A. Trompenaars, D. Bell, G. Hofstede, F. Fukuyama, S. P. Huntington, L. C. Thurow i inni.

7 Poziom ten wynosił odpowiednio: kraje represyjne - 7716, kraje raczej zniewolone - 7829, umiarkowanie wolne - 22 382, raczej wolne - 47 742, wolne - 63588 USD [Miller i in., 2019, s. 25-26].
} 
W ostatnich pięciu latach tempo wzrostu PKB w krajach, w których zmniejszała się wolność gospodarcza wynosiło 1\%, a w krajach, w których się zwiększała - 2,3\%. W ostatnim dwudziestopięcioleciu wyniki te wypadaja podobne - 1,5\% i 2,6\% [Miller i in., 2019, s. 25-26].

Powyższych badań nie można bezpośrednio przełożyć na modele gospodarcze. Wynika to z tego, że pewne cechy charakterystyczne są dla większej liczby modeli, poszczególne modele nie są czymś stałym, ciagle ewoluuja, w teorii ekonomii pojawiają się nowe modele, co związane jest z ciagłymi zmianami w gospodarce i polityce gospodarczej. Niektóre z nich niekiedy zbyt krótko funkcjonuja, żeby wyciagnąć wnioski co do ich wpływu na wzrost gospodarczy i jego stabilność. Wiele krajów nie da się jednoznacznie zakwalifikować do któregoś z funkcjonujących modeli rynku (kapitalizmu). Z tego względu brak jest większej ilości badań, które by jednoznacznie formułowały, które modele są lepsze, a które gorsze z punktu widzenia wzrostu gospodarczego. W tym miejscu warto by jeszcze dodać, że waga wzrostu gospodarczego dla poszczególnych krajów jest bardzo zróżnicowana, inna dla krajów biednych, a inna dla krajów bogatych.

W literaturze pojawiły się próby wyjaśnienia różnic w tempie wzrostu gospodarczego krajów transformujących. Różnice te - zdaniem autorów tych opracowań wynikały z przyjętego modelu gospodarczego. Przykładowo, wyższe tempo wzrostu gospodarczego Estonii w porównaniu ze Słowenią było wynikiem wdrożenia modelu neoliberalnego w pierwszym kraju i modelu socjaldemokratycznego w drugim [Cwalina, 2010]. Interesujący jest również przykład Czech i Słowacji. Wyższe tempo wzrostu gospodarczego Słowacji tłumaczy się zmianą modelu społeczno-gospodarczego w okresie reform gospodarczych Dziurindy (w stronę modelu neoliberalnego), które nastąpiły po okresie rządów Meciara [Miklos, 2010]. Z kolei w Czechach kierunek był odwrotny - przejście od liberalnej wizji Klausa (czeska wersja demokratycznego kapitalizmu o przewadze cech wolnorynkowych) do zawierającego elementy państwa socjalnego i skłonności do regulacji według wzorca społeczno-gospodarczego panującego w kontynentalnej Europie [Dyba, 2010]. Z takimi porównaniami między innymi krajami - zarówno wysoko rozwiniętymi, jak i rozwijającymi się - bez odwoływania się do znanych z opracowań modeli gospodarki rynkowej/kapitalizmu również spotykamy się w literaturze. Podkreśla się w nich, że czynniki instytucjonalne miały wpływ na zróżnicowane tempo wzrostu gospodarczego ${ }^{8}$.

\section{Tempo wzrostu gospodarczego w wybranych krajach (analiza empiryczna)}

Tempo wzrostu gospodarczego (przyrost realnego PKB w stosunku do roku poprzedniego) w analizowanej grupie krajów w latach 2004-2018 pokazuje tabela 1.

\footnotetext{
8 Chociażby porównanie tempa wzrostu gospodarczego Australii i Nowej Zelandii, Austrii i Szwajcarii, Wenezueli i Chile czy Haiti i Dominikany [Zagadki wzrostu gospodarczego..., 2010].
} 
TABELA 1

Tempo wzrostu realnego PKB

\begin{tabular}{|c|c|c|c|c|c|c|c|c|}
\hline Lata & 2004 & 2005 & 2006 & 2007 & 2008 & 2009 & 2010 & 2011 \\
\hline Dania & 2,4 & 2 & 3,6 & 0,5 & $-0,5$ & $-4,9$ & 1,9 & 1,3 \\
\hline Niemcy & 1,3 & 0,9 & 3,9 & 3,5 & 1 & $-5,7$ & 4,2 & 3,9 \\
\hline Irlandia & 4,9 & 3,4 & 3,1 & 0,7 & $-4,5$ & $-5,1$ & 1,8 & 0,3 \\
\hline Grecja & 4,8 & 0,3 & 5,3 & 3 & $-0,3$ & $-4,3$ & $-5,5$ & $-9,1$ \\
\hline Hiszpania & 1,6 & 1,8 & 2,5 & 1,8 & 0,9 & $-3,8$ & 0,2 & $-0,8$ \\
\hline Włochy & 0,8 & 0,3 & 1,6 & 0,9 & -1 & $-5,3$ & 1,7 & 0,7 \\
\hline Holandia & 1,7 & 1,9 & 3,4 & 3,5 & 2,2 & $-3,7$ & 1,3 & 1,6 \\
\hline Austria & 2,1 & 1,4 & 2,8 & 3,3 & 1,5 & $-3,8$ & 1,8 & 2,9 \\
\hline Szwecja & 3,9 & 2,4 & 4,1 & 2,6 & $-0,2$ & $-4,2$ & 6,2 & 3,1 \\
\hline W.B. & 2 & 2,2 & 1,8 & 1,7 & $-0,3$ & $-4,2$ & 1,9 & 1,5 \\
\hline Norwegia & 3,3 & 1,9 & 1,6 & 1,9 & 0,5 & $-1,7$ & 0,7 & 1 \\
\hline USA & 3,8 & 3,5 & 2,9 & 1,9 & $-0,1$ & $-2,5$ & 2,6 & 1,6 \\
\hline Lata & 2012 & 2013 & 2014 & 2015 & 2016 & 2017 & 2018 & \\
\hline Dania & 0,2 & 0,9 & 1,6 & 2,3 & 3,2 & 2 & 2,4 & \\
\hline Niemcy & 0,4 & 0,4 & 2,2 & 1,7 & 2,2 & 2,5 & 1,5 & \\
\hline Irlandia & 0,2 & 1,4 & 8,6 & 25,2 & 3,7 & 8,1 & 8,2 & \\
\hline Grecja & $-7,3$ & $-3,2$ & 0,7 & $-0,4$ & $-0,2$ & 1,5 & 1,9 & \\
\hline Hiszpania & -3 & $-1,4$ & 1,4 & 3,8 & 3 & 2,9 & 2,4 & \\
\hline Włochy & -3 & $-1,8$ & 0 & 0,8 & 1,3 & 1,7 & 0,8 & \\
\hline Holandia & -1 & $-0,1$ & 1,4 & 2 & 2,2 & 2,9 & 2,6 & \\
\hline Austria & 0,7 & 0 & 0,7 & 1 & 2,1 & 2,5 & 2,4 & \\
\hline Szwecja & $-0,6$ & 1,1 & 2,7 & 4,4 & 2,4 & 2,4 & 2,2 & \\
\hline W.B. & 1,5 & 2,1 & 2,6 & 2,4 & 1,9 & 1,9 & 1,3 & \\
\hline Norwegia & 2,7 & 1 & 2 & 2 & 1,1 & 2,3 & 1,3 & \\
\hline USA & 2,3 & 1,8 & 2,5 & 2,9 & 1,6 & 2,2 & 2,9 & \\
\hline
\end{tabular}

Źródło: [www 1; www 2; www 3].

W latach 2004-2007 tempo wzrostu gospodarczego było we wszystkich krajach dodatnie i relatywnie wysokie. W tym okresie najwyższy wzrost PKB (powyżej 3,5\%) odnotowały: Grecja (5,3\% w 2006 i 4,8\% w 2004 r.), Irlandia (4,9\% w 2004 r.), Szwecja (4,1\% w 2006 r. i 3,9\% w 2004 r.), Niemcy (3,9\% w 2006 r.) oraz USA (3,8\% w 2004 r.), a najniższy (poniżej 0,8\%): Grecja i Włochy (0,3\% w 2005 r.), Dania (0,5\% w 2007 r.) oraz Irlandia (0,7\% w 2007 r.). Załamanie nastapiło w 2008 roku, kiedy 7 krajów odnotowało ujemne tempo wzrostu. Najwyższe - aż $-4,5 \%-$ zanotowała Irlandia, a dalej Włochy $(-1 \%)$. W pozostałych krajach spadek ten wynosił poniżej 1\%. W roku 2008 PKB zmniejszył się już we wszystkich krajach, najbardziej w Niemczech, Włoszech i Irlandii (powyżej 5\%), a najmniej w Norwegii 
(poniżej 2\%). Światowy kryzys nie był więc aż tak dotkliwy. Poprawa koniunktury nastąpiła już w 2010 r., w którym wszystkie kraje - z wyjątkiem Grecji - odnotowały dodatni wzrost gospodarczy, najwyższy Szwecja $(6,2 \%)$ i Niemcy $(4,2 \%)$. Grecja, w której spadek PKB wynosił 5,5\%, miała największe problemy z wyjściem z kryzysu. W kolejnych latach spadek był tam jeszcze wyższy (2011-2012) i utrzymywał się - z wyjątkiem 2014 - do roku 2016. Nałożyło się na to wiele innych czynników, w tym kryzys walutowy i finansów publicznych. Jednak poprawa koniunktury we wskazanych krajach była krótkotrwała. W 2011 roku ujemne tempo wzrostu oprócz Grecji odnotowała już Hiszpania, a w roku następnym również Włochy, Holandia i Szwecja. Jeżeli chodzi o pozostałe kraje, to większość z nich miała bardzo niskie tempo wzrostu. Ujemne tempo wzrostu gospodarczego występowało także w 2013 r. (4 kraje), a dodatni wzrost we wszystkich krajach pojawił się dopiero w 2014 r.. Z wyjątkiem wspomnianej już Grecji trwał on do 2018 r. (koniec analizowanego okresu). Najlepsze wyniki w tym okresie osiagnęła Irlandia z nieprawdopodobnym wynikiem (25\%!) w 2015 r. W roku 2018 wzrost ten wynosił około $8 \%$, podczas gdy w pozostałych krajach nie przekroczył 3\% (najbliżej tego wyniku były USA z 2,9\% wzrostem PKB). Najniższe tempo wzrostu gospodarczego $(0,8 \%)$ odnotowały Włochy.

\section{Omówienie wyników badań}

Dane statystyczne dotyczące tempa wzrostu gospodarczego w poszczególnych latach w analizowanej grupie krajów zawarte w tabeli 1 pozwalają nam na obliczenie: średniorocznego tempa wzrostu PKB w latach 2004-2018 (średnia arytmetyczna za wszystkie lata), średniorocznego tempa wzrostu PKB w latach 2007-2011 (to jest za okres obejmujący lata dobrej koniunktury bezpośrednio przed wybuchem kryzysu, załamania gospodarczego oraz wychodzenia $\mathrm{z}$ największego kryzysu XXI wieku), różnicy między średniorocznym tempem wzrostu PKB za te dwa okresy, amplitudy wahań (różnicy między maksymalnym a minimalnym średniorocznym tempem wzrostu PKB w latach 2004-2018), liczby lat z ujemnym tempem wzrostu gospodarczego oraz z tempem wzrostu gospodarczego mniejszym niż $1 \%$. Informacje na ten temat podaje tabela 2. Zawarto w niej również obliczenia dotyczące wzrostu PKB w poszczególnych krajach w stosunku do średniej unijnej (UE-28 = 100).

Dane w tabeli 2 to $\mathrm{w}$ zasadzie ranking krajów w wymienionych powyżej kategoriach. Ich kolejność jest zgodna z osiagniętym wynikiem. Z pewnym uproszczeniem można powiedzieć, że kraje zostały uszeregowane od „najlepszych” do „najgorszych" (chociaż nie jest to tak jednoznaczne w przypadku niektórych kolumn, co zostanie później wyjaśnione). Analizując miejsca zajęte przez poszczególne kraje, które reprezentują cztery odmienne modele gospodarki rynkowej, możemy się pokusić o pokazanie wpływu tych modeli na tempo wzrostu gospodarczego oraz jego zmiany. 
TABELA 2

\section{Ranking krajów}

\begin{tabular}{|c|c|c|c|}
\hline $\begin{array}{c}\text { Średnioroczne } \\
\text { tempo wzrostu PKB } \\
\text { 2004-2018 } \\
(\%)\end{array}$ & $\begin{array}{c}\text { Średnioroczne } \\
\text { tempo wzrostu } \\
\text { PKB 2007-2011 } \\
(\%)\end{array}$ & $\begin{array}{c}\text { Różnica między } \\
\text { średniorocznym } \\
\text { tempem wzrostu za lata } \\
\text { 2004-2018 oraz 2007-2011 } \\
\text { (p. p.) }\end{array}$ & $\begin{array}{l}\text { Amplituda } \\
\text { wahań } \\
\text { max. - min. } \\
\text { (p. p.) }\end{array}$ \\
\hline Irlandia 4 & Szwecja 1,5 & Niemcy 0,2 & Norwegia 5 \\
\hline Szwecja 2,2 & Niemcy 1,4 & Austria 0,3 & USA 6,1 \\
\hline USA 2 & Austria 1,1 & Holandia 0,5 & W.B. 6,6 \\
\hline Niemcy 1,6 & Holandia 1 & Włochy 0,6 & Włochy 7 \\
\hline \multirow{2}{*}{$\begin{array}{l}\text { Holandia } 1,5 \\
\text { Norwegia } 1,5\end{array}$} & USA 0,7 & Szwecja 0,7 & Austria 7,1 \\
\hline & Norwegia 0,5 & \multirow{2}{*}{$\begin{array}{c}\text { Grecja } 1 \\
\text { Norwegia } 1\end{array}$} & Holandia 7,2 \\
\hline Austria 1,4 & W.B. 0,1 & & Hiszpania 7,6 \\
\hline \multirow{2}{*}{$\begin{array}{l}\text { Dania } 1,3 \\
\text { W.B. } 1,3\end{array}$} & \multirow{2}{*}{$\begin{array}{c}\text { Dania }-0,3 \\
\text { Hiszpania }-0,3\end{array}$} & \multirow{2}{*}{$\begin{array}{c}\text { Hiszpania 1,2 } \\
\text { W.B. 1,2 }\end{array}$} & Dania 8,5 \\
\hline & & & Niemcy 9,9 \\
\hline Hiszpania 0,9 & Włochy $-0,6$ & USA 1,3 & Szwecja 10,4 \\
\hline Włochy 0 & Irlandia $-1,4$ & Dania 1,6 & Grecja 14,4 \\
\hline Grecja -2,2 & Grecja -3,2 & Irlandia 5,4 & Irlandia 30,3 \\
\hline $\begin{array}{c}\text { Liczba lat } \\
\text { z ujemnym tempem } \\
\text { wzrostu }\end{array}$ & $\begin{array}{c}\text { Liczba lat } \\
\text { z tempem wzrostu } \\
\text { mniejszym niż 1\% }\end{array}$ & $\begin{array}{l}\text { Wzrost w stosunku } \\
\text { do średniej UE } \\
\text { (UE28=100) 2005-2018 } \\
\text { (p. p.) }\end{array}$ & \\
\hline \multirow{3}{*}{$\begin{array}{c}\text { Austria } 1 \\
\text { Niemcy } 1 \\
\text { Norwegia } 1\end{array}$} & \multirow{2}{*}{$\begin{array}{l}\text { USA } 2 \\
\text { W.B. } 2\end{array}$} & Irlandia +42 & \\
\hline & & Dania +4 & \\
\hline & \multirow{3}{*}{$\begin{array}{c}\text { Holandia } 3 \\
\text { Norwegia } 3 \\
\text { Szwecja } 3\end{array}$} & Niemcy +4 & \\
\hline \multirow{4}{*}{$\begin{array}{l}\text { Dania } 2 \\
\text { Irlandia } 2 \\
\text { USA } 2 \\
\text { W.B. } 2\end{array}$} & & Austria 0 & \\
\hline & & Szwecja -3 & \\
\hline & \multirow{2}{*}{$\begin{array}{l}\text { Niemcy } 4 \\
\text { Austria } 4\end{array}$} & Holandia -6 & \\
\hline & & Hiszpania -9 & \\
\hline \multirow{2}{*}{$\begin{array}{c}\text { Holandia } 3 \\
\text { Szwecja } 3\end{array}$} & Dania 5 & W.B. -12 & \\
\hline & Irlandia 5 & Włochy -13 & \\
\hline \multirow{2}{*}{$\begin{array}{c}\text { Hiszpania } 4 \\
\text { Włochy } 4\end{array}$} & Hiszpania 6 & USA -21 & \\
\hline & Grecja 10 & Norwegia -22 & \\
\hline Grecja 8 & Włochy 11 & Grecja -25 & \\
\hline
\end{tabular}

Źródło: opracowanie własne na podstawie [www 1; www 2; www 3].

Najbardziej widoczny wydaje się wpływ modelu śródziemnomorskiego na wzrost gospodarczy i jego wahania. Pokazuje to duży stopień skupienia tych krajów, które zajmują w poszczególnych rankingach sąsiednie miejsca i to - najczęściej - w dolnej części tabeli. To sugeruje, że kraje te najgorzej radzą sobie ze wzrostem gospodar- 
czym i jego stabilizacją. Średnioroczne tempo wzrostu PKB w latach 2004-2018 było tam najniższe (od $0,9 \%$ we Włoszech do $-2,2 \%$ w Grecji). Pod tym względem kraje te zajmuja 3 ostatnie miejsca. Podobnie jest w przypadku lat 2007-2011 (tylko Irlandia rozdzieliła te kraje). Również trzy ostatnie miejsca - ze znacznie gorszymi wynikami w porównaniu $\mathrm{z}$ pozostałymi - zajęły te kraje $\mathrm{w}$ kategorii liczby lat z ujemnym lub mniejszym niż $1 \%$ tempem wzrostu PKB. Nieco wyższa pozycja w trzeciej i czwartej kolumnie jest rezultatem bardzo niskiego tempa wzrostu gospodarczego (kolumna pierwsza i druga) i nie należy oceniać tego pozytywnie. Kraje te również najwięcej straciły, jeżeli chodzi o poziom PKB w stosunku do średniej unijnej. Nie licząc nienależących do UE Norwegii i USA (na marginesie są to znacznie bogatsze państwa), kraje te zajmują ostatnie miejsca (jedynie Hiszpania wyprzedziła Wielką Brytanię).

Wydaje się, że na taką pozycję omawianych krajów wpłynął system gospodarczy. Model śródziemnomorski cechuje się bowiem słabo rozwiniętymi instytucjami, niskim poziomem zarządzania publicznego, dużym udziałem szarej strefy w gospodarce, wysokim wskaźnikiem korupcji itp. To ma przełożenie na wzrost gospodarczy, a może w jeszcze większym stopniu na utrzymanie jego stabilności. Z tego względu kraje te również najgorzej radziły sobie z kryzysem gospodarczym I dekady XXI wieku.

Duże podobieństwo istnieje również w przypadku krajów reprezentujących model społecznej gospodarki rynkowej. Osiagnęły one bardzo zbliżone wyniki. Widać to najwyraźniej w przypadku średniorocznego tempa wzrostu gospodarczego za ostatnie 15 lat, które kształtowało się na poziomie 1,4-1,6\% (jest to przeciętny poziom w całej analizowanej grupie krajów). Identycznie było w latach kryzysu. Tempo wzrostu gospodarczego było tam podobne (1,0-1,4\%), a ponadto - co należy podkreślić - relatywnie wysokie. Kraje te zajęły miejsca od 2 do 4, w dodatku tylko nieznacznie ustępuja pierwszej w rankingu Szwecji. W efekcie różnica między średniorocznym tempem wzrostu PKB w tych dwóch okresach była tam minimalna (trzy pierwsze miejsca w kolumnie trzeciej). Wysokie pozycje kraje te zajmuja ponadto $\mathrm{w}$ rankingu liczby lat $\mathrm{z}$ ujemnym wzrostem gospodarczym, a nieco niższą w przypadku liczby lat z niskim tempem wzrostu PKB (również duże podobieństwo między nimi). W stosunku do średniego unijnego poziomu PKB per capita straciła tylko Holandia, nie zmieniła się pozycja Austrii, a zyskały Niemcy. Zważywszy na to, że są to bogate państwa, wynik ten należy ocenić pozytywnie.

$\mathrm{Na}$ pozycję tych państw z pewnością wpływ miał funkcjonujący w nich model gospodarczy, który zwraca szczególną uwagę nie tylko na sferę socjalną, ale również na politykę gospodarczą w sferze stabilności wzrostu gospodarczego. Z pewnością pozytywnie oddziałują również ustabilizowane instytucje, zarządzanie gospodarcze $i$ inne. Są to cechy tego modelu. Zwraca się tutaj uwagę nie tyle na tempo wzrostu, ile przede wszystkim na jego stabilność. Oznacza to, że w tym modelu kraje nieźle sobie radzą z kryzysem i wahaniami w gospodarce.

Mniejszy stopień podobieństwa zauważalny jest w przypadku krajów zaliczonych do modelu neoliberalnego. $\mathrm{Z}$ pewnością byłoby ono znacznie wyższe, gdyby nie Irlandia, która odstaje od USA i Wielkiej Brytanii (jedynie w przypadku tych dwóch 
krajów podobieństwo jest zdecydowanie większe, co widać prawie we wszystkich kolumnach). Odnosi się to do niemal wszystkich wskaźników. Widzimy tutaj bardzo wysokie tempo wzrostu w latach 2004-2018 oraz bardzo niskie w latach kryzysu. Różnica między nimi, jak i amplituda wahań są największe. Pod tym względem Irlandia odbiega od wszystkich pozostałych 11 krajów. Pomimo tych wahań kraj ten znacznie zwiększył (Wielka Brytania i USA zmniejszyły) swój poziom PKB w stosunku do średniej unijnej. Jedyna zbieżność występuje w przypadku liczby lat z ujemnym tempem wzrostu gospodarczego.

Oceniając powyższe różnice i podobieństwa, można stwierdzić, że to, co się dzieje w Irlandii, jest jak najbardziej charakterystyczne dla modelu liberalnego, a nawet skrajnie liberalnego. Czyżby więc uczeń przerósł mistrza? Czy liberalizm amerykański i brytyjski jest bardziej okiełznany? Z pewnością tak nie jest i przyczyn takiego stanu rzeczy jest znacznie więcej. Należałoby - dla przykładu - wspomnieć o niższym poziomie rozwoju gospodarczego w Irlandii w przeszłości, umiejętnym wykorzystaniu członkostwa w WE/UE, dużym napływie kapitału amerykańskiego i związaną z tym koniecznością otwarcia się również na napływ siły roboczej (stąd znacznie wyższy PKB w stosunku do PNB). Tak więc powyższe czynniki, a także liberalne podejście do gospodarki i z pewnościa jeszcze wiele innych spowodowały tak duże różnice między Irlandią a Wielką Brytanią i USA. Z kolei analizując wyniki, które uzyskały te dwa ostatnie kraje, można stwierdzić, że widoczne jest tam bardziej liberalne podejście do gospodarki w porównaniu z modelem społecznej gospodarki rynkowej (ordoliberalizm), a na jego ograniczenie wpływ z pewnościa miał kryzys gospodarczy, który nieco zmienił ich podejście..

Najmniejsze podobieństwo widać wśród krajów reprezentujących model państwa dobrobytu. Inaczej mówiąc, rozrzut między nimi jest największy. W przypadku średniorocznego tempa wzrostu w latach 2004-2018 wynosił on 0,9 p. p., a w latach 2007-2011 aż 1,8 p. p. W krajach o społecznej gospodarce rynkowej było to odpowiednio 0,2 i 0,4 p. p., a w przypadku USA i Wielkiej Brytanii 0,7 i 0,6 p. p. Bardzo duży rozrzut odnotowano również, jeżeli chodzi o różnice miedzy nimi (trzecia kolumna) oraz amplitudę wahań (czwarta kolumna). Mniejsze różnice wystąiły jedynie w przypadku liczby lat z ujemnym i niskim tempem wzrostu gospodarczego (kolumna piąta i szósta).

Powyższe dane pokazuja, jakoby model ten w najmniejszym stopniu wpływał na tempo wzrostu gospodarczego i jego wahania. Warto dodać, że największe różnice uwidaczniają się między Szwecją i Danią, a więc krajami najbardziej kojarzonymi z modelem państwa dobrobytu. Czym można to wytłumaczyć? Czyżby przykładając większą wagę do sfery redystrybucji, kraje te mniej troszczą się o sferę produkcji? Niekoniecznie tak musi być, ale podobieństwa między tymi krajami w tej sferze są zdecydowanie mniejsze. Mamy tutaj raczej do czynienia $z$ większym indywidualizmem (np. rynek pracy jest bardziej elastyczny w Danii w porównaniu ze Szwecją) - stąd takie wyniki. 


\section{Podsumowanie}

Przedstawione badania nad wpływem systemu gospodarczego na wzrost gospodarczy i jego wahania pozwalają na wyciągnięcie następujących wniosków:

1. Średnioroczne tempo wzrostu gospodarczego oraz jego wahania są zróżnicowane w poszczególnych krajach.

2. Między niektórymi z nich istnieje pod tym względem duże podobieństwo. Tak się składa, że najczęściej są to kraje reprezentujące ten sam model gospodarki rynkowej.

3. Najbardziej zbliżone do siebie są kraje reprezentujące model śródziemnomorski oraz model społecznej gospodarki rynkowej. O pewnym podobieństwie możemy również mówić w przypadku dwóch krajów zaliczanych do modelu neoliberalnego (Wielkiej Brytanii i USA), a o jego braku w modelu państwa dobrobytu.

4. Można zauważyć, że najgorzej ze wzrostem gospodarczym oraz jego stabilnością radzą sobie kraje reprezentujące model śródziemnomorski. Z kolei stabilność wzrostu gospodarczego i dobre radzenie sobie z cyklicznością charakterystyczne jest dla państw realizujących model społecznej gospodarki rynkowej. Wysokie długookresowe tempo wzrostu gospodarczego z jednej strony oraz duże wahania z drugiej to cecha modelu liberalnego, ale występująca jedynie w przypadku Irlandii. Trudno określić specyfikę modelu państwa dobrobytu, jeżeli chodzi o wzrost gospodarczy i jego wahania.

5. Powyższe badania w dużym stopniu potwierdzają hipotezę o wpływie systemu gospodarczego na tempo wzrostu gospodarczego i jego wahania.

\section{Literatura}

Aiginger K., Guger A., 2005, The European socio-economic model. Differences to the USA and changes over time, „,WIFO Working Papers”, no. 266, pp. 1-38.

Albert M., 1994, Kapitalizm kontra kapitalizm, Signum, Kraków.

Amable B., 2003, The diversity of modern capitalism, Oxford University Press, Oxford.

Balcerowicz L., 2008, Institutional systems and economic growth, [in:] Challenges of globalization: imbalances and growth, Aslund M., Dabrowski M, (ed.), Peterson Institute for International Economics, Washington D.C.

Coates D., 2000, Models of capitalism. Growth and stagnation in the Modern Era, Polity Press, Cambridge.

Cwalina P., 2010, Skead sie wzieły różnice we wạoście gospodarçym miedzy Estonia a Stowenia?, [w:] Zagadki wrrostu gospodarczego. Sity napedowe i kryzysy - analiza porównawcza, Balcerowicz L., Rzońca A. (red.), Wydawnictwo C.H. Beck.

Dyba K., 2010, Czeski model spoleczno-gospodarczy i jego ewolucja od poczatku transformacji do roku 2007, [w:] Wrrost gospodarçy çy bezpieczeństwo socjalne?, Bieńkowski W., Radło M.J. (red.), Wydawnictwo Naukowe PWN, Warszawa. 
Hall P.A., Soskice D., 2001, Introduction, [in:] Varieties of capitalism. The institutional foundation of comparative advantage, Hall P.A., Soskice D. (ed.), Oxford University Press, Oxford.

Hutton W., 1996, The state we're in, Vintage, London.

Maszczyk P., 2015, Ewolucja modelu kapitalizmu w Polsce, „Nierówności Społeczne a Wzrost Gospodarczy", nr 41, s. 107-122.

Miklos I., 2010, Stowacja: historia reform, [w:] Wrerost gospodarçy čy bespieczeństwo socjalne?, Bieńkowski W., Radło M.J. (red.), Wydawnictwo Naukowe PWN, Warszawa.

Miller T., Kim A.B., Roberts J.M., 2019, 2019 Index of economic freedom. 25th anniversary edition, The Heritage Foundtion, Washington D.C.

Rapacki R., Gardawski J., Czerniak A., Horbaczewska B., Karbowski A., Maszczyk P., Próchniak M., 2018, Wyłaniajace sie odmiany kapitalizmu w Europie Środkowo-W Schodniej: preeglad badan, „Ekonomista”, nr 5, s. 523-553.

Systemowe uwarunkowania wərostu $i$ rozwoju gospodarczego. Zagadnienia teoretyczne, 2013, Swadźba S. (red.), Wydawnictwo Uniwersytetu Ekonomicznego w Katowicach, Katowice.

Wojtyna A., 2005, Alternatywne modele kapitalizmu, „Gospodarka Narodowa”, nr 9, s. $1-23$.

Zagadki wzrostu gospodarczego. Sity napedowe i krysysy - analiza porównawrza, 2010, Balcerowicz L., Rzońca A. (red.), Wydawnictwo C.H. Beck.

www 1, http://ec.europa.eu/eurostat/tgm/table [data dostępu: 20.07.2015]. www 2, https://ec.europa.eu/eurostat/data/database [data dostępu: 20.01.2020]. www 3, https://data.worldbank.org/indicators/ [data dostępu: 20.01.2020]. 